\title{
Hierarchical control of phytoplankton succession by physical factors
}

\author{
Maurice Levasseur ${ }^{1}$, Jean-Claude Therriault ${ }^{1}$ and Louis Legendre ${ }^{2}$ \\ ${ }^{1}$ Champlain Centre for Marine Sciences and Surveys, Department of Fisheries and Oceans, Canada, P. O. Box 15500, 901 Cap \\ Diamant, Québec, Québec G1K 7Y7, Canada \\ ${ }^{2}$ GIROQ, Departement de biologie, Université Laval, Québec, Québec G1K 7P4, Canada
}

\begin{abstract}
The influence of physical factors on phytoplankton succession was assessed during an annual cycle in the St. Lawrence Estuary (Canada), where nutrients remain abundant throughout the whole year. Typically, the phytoplankton production period is short (Jun to Sep) and characterized by the occurrence of 3 distinct peaks. The July bloom was dominated by the 2 diatoms Thalassiosira nordenskioldii and Chaetoceros debilis, while Leptocylindrus minimus and Nitzschia seriata were dominant at the beginning and at the end of September, respectively. The occurrence of the 3 bloom periods is related to an increase in mean light intensity in the mixed layer, caused by strong density stratification which decreases the depth of the mixed layer. During these bloom periods, the succession of diatom species is mainly controlled by variations in temperature. Flagellates were observed all yearround, although they were more abundant during the diatom bloom periods. Their abundance is related to variations in surface temperature. In the Estuary, where nutrients are usually non-limiting, the observed succession of taxa is restricted to the first stage of the Margalef (1958) succession model (small cells with high growth rates, which are typical species for frequently destabilized environment). Our results demonstrate that the frequency of destabilization of the water column selects the growth rates of the cells, through nutrient conditions. Mean light intensity in the mixed layer determines the occurrence of non-motile forms such as diatoms, and temperature sets the conditions for optimal metabolic activity (flagellate numbers and succession of diatom species). This results in a conceptual model where stability conditions, mean light in the mixed layer and temperature hierarchically control phytoplankton succession.
\end{abstract}

\section{INTRODUCTION}

According to the early models of Margalef (1958, 1963, 1967) and Smayda (1963), one of the most obvious factors that account for the sequence of events in a typical marine phytoplankton succession is replenishment and depletion of nutrients in the mixed layer. Phytoplankton succession starts upon stabilization of the water column, after a period of intense vertical mixing, and progresses toward a more complex community structure as long as some vertical stability persists in the water column. The typical succession pattern is divided into 3 stages (Margalef, 1958). Stage $I$ is characterized by fast growing, small-celled diatoms, Stage II involves the occurrence of a community of larger diatoms with lower growth rates, and Stage III is determined by the presence of large dinoflagellates with still lower growth rates. The gradual change from Stage I to Stage III follows the progressive depletion of nutrients, while intense destabilization of the water column determines the end of a succession or the beginning of a new one.

If nutrients effectively play such an important role for the control of phytoplankton succession, important changes in the community structure should not occur in such highly energetic environments as estuaries, where intense and frequent vertical mixing leading to destabilization of the water column, and consequently high nutrient concentrations, would continuously set back succession. But true phytoplankton succession (not linked to advective processes) has also been observed in this type of environment (Riley, 1957; Patten et al., 1963; Durbin et al., 1975; Sinclair, 1978; Walting et al., 1979). In addition, a number of studies have indicated that a succession of different taxonomic groups of algae (flagellates to diatoms to dinoflagellates) could result from the adaptation of phytoplankton cells to different vertical mixing conditions, inde- 
pendent of nutrient availability (Hutchinson, 1967; Margalef, 1978; Margalef et al., 1979; Harris and Piccinin, 1980). Among other possible controlling factors, temperature and grazing by zooplankton have been identified as potentially important (Smayda, 1963; Martin, 1970; Durbin et al., 1975; Malone, 1977b; Ryther and Sanders, 1980; Malone and Neale, 1981). Recent works by Ignatiades (1979), Malone and Chervin (1979) and Bowman et al. (1981) have also given evidence of a strong association between vertical stratification and the relative abundance of flagellates and diatoms in coastal waters. The present knowledge therefore suggests that some physical factors are as important as nutrients for the control of phytoplankton succession in coastal waters.

This study was designed to assess, in an environment where nutrients are always abundant, the role of the various physical factors in controlling phytoplankton succession. We wanted to check if the major morphological groups (naked flagellates vs diatoms vs dinoflagellates) are selected by environmental factors different from those controlling the succession of species within these groups, so as to establish some hierarchy among the physical factors.

\section{MATERIALS AND METHODS}

Sampling was carried out in the St. Lawrence Estuary, at a station (40 $\mathrm{m}$ deep) located $4.5 \mathrm{~km}$ offshore Rimouski (Fig. 1). This station was occupied twice a week, from 19 June to 15 December 1979 and from 2 May to 25 July 1980 . Occasional samples were also

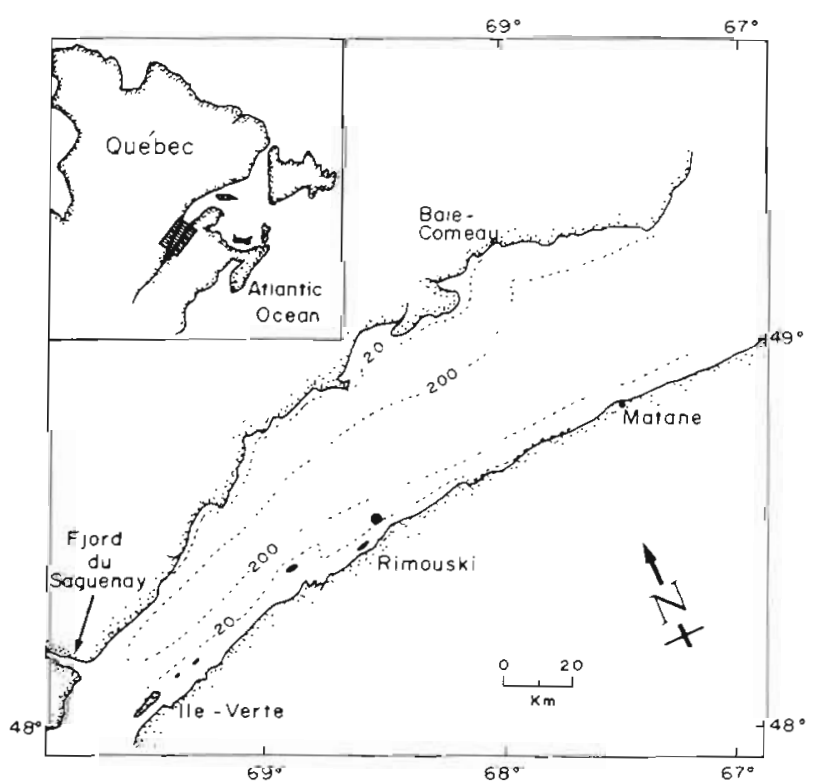

Fig. 1. Location of sampling station in the St. Lawrence Estuary (Canada) taken during the winter period (10 Feb and $23 \mathrm{Mar}$ 1980).

On each sampling date, measurements of turbidity (Secchi disk) and vertical profiles of temperature (bathythermograph) and of light intensity (submarine photometer, Kalt Scientific Instrument Corp. model 268 WA310) were first obtained. Then 3 sets of 8 water samples (31 Van Dorn bottles) were collected from depths corresponding to $100,60,30,16$ and $1 \%$ of the surface incident light and, under the photic zone, from fixed depths ( 51 Niskin bottles) at 15,20 and $35 \mathrm{~m}$. The sampling interval between the 3 bottle casts was $15 \mathrm{~min}$. The 24 samples obtained ( $3 \times 8$ depths) were stored in the dark during the return trip to the shore laboratoy ( $45 \mathrm{~min}$ ), at Pointe-au-Père.

Photosynthetic activity of phytoplankton was determined using the ${ }^{14} \mathrm{C}$ uptake method described in Strickland and Parsons (1972). Samples were inoculated with the ${ }^{14} \mathrm{C}$ solution, covered with a nylon net reproducing the light intensity at the sampling depth and incubated for $4 \mathrm{~h}$ under natural light. Circulating surface sea water kept the temperature of incubation constant. Two $50 \mathrm{ml}$ sub-samples from each water sample were filtered through Whatman GF/C filters, which were frozen for further determination of chlorophyll a and phaeopigments using the fluorometric method of Yentsch and Menzel (1963) as modified by Holm-Hansen et al. (1965). The filtrate from each sub-sample was frozen into $50 \mathrm{ml}$ polyethylene bottles (immersed for at least $24 \mathrm{~h}$ in a $15 \% \mathrm{HCl}$ solution before rinsing with distilled water) for further determination (within two months) of nutrients (phosphate, nitrate and silicate) using a Technicon Auto-analyser (Strickland and Parsons, 1972). Another $50 \mathrm{ml}$ sub-sample was fixed with $5 \mathrm{ml}$ of acid Lugol and kept for further enumeration of phytoplankton cells using the Utermöhl technique (Lund et al., 1958). Salinity was determined with an induction salinometer (Auto-Salt 8400). During the whole sampling period, solar radiation was recorded with a Weather Measure Corporation (R-401) pyranometer, installed on top of the shore laboratory.

\section{RESULTS}

\section{Chemical and physical factors}

Nutrients are generally abundant at the sampling station (Fig. 2) and concentrations under 1.0, 0.2 and $10.0 \mu \mathrm{g}$ at $\mathrm{l}^{-1}$ for nitrate, phosphate and silicate, respectively, are only rarely observed. The 3 nutrients show a similar pattern of seasonal variations, which is characterized by higher concentrations from October to May and lower concentrations due to phytoplankton utilization from June to September. 


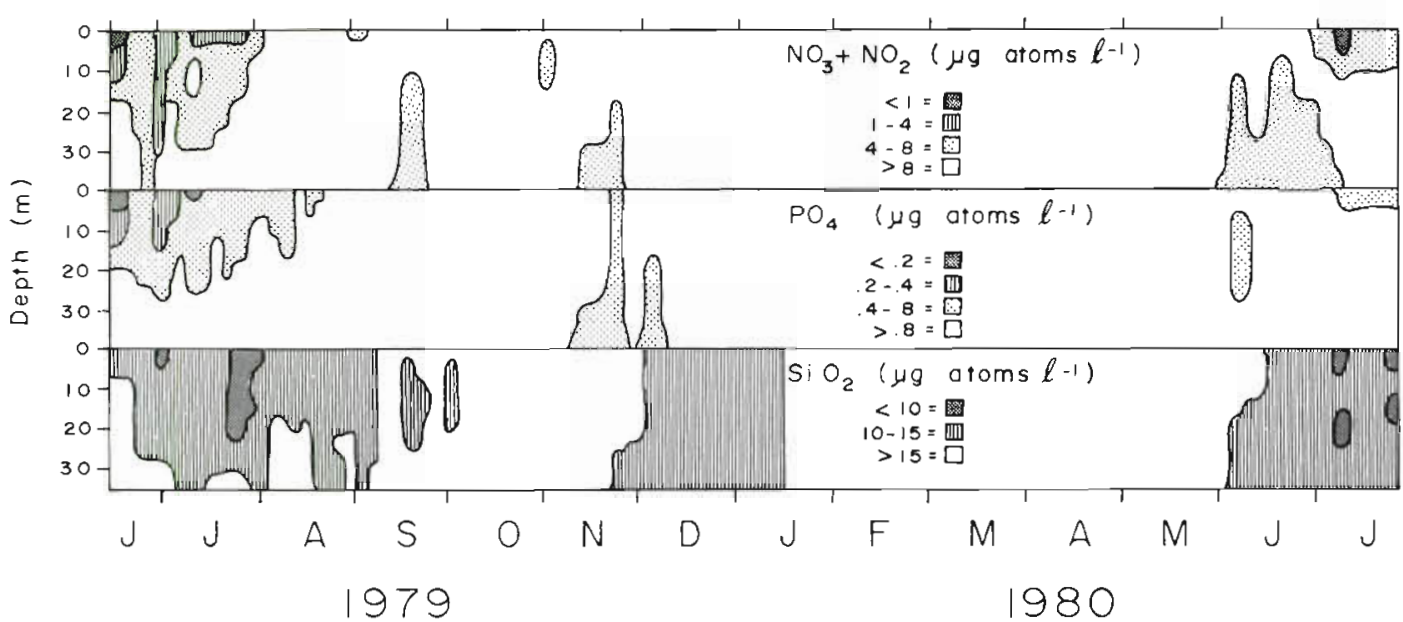

Fig. 2. Temporal variations of nitrate, phosphate and silicate

From December to April (Fig. 3), the water column is only weakly stratified and characterized by low temperatures $\left(\leqslant 0^{\circ} \mathrm{C}\right)$ and high salinities (>27\%). Maximum freshwater runoff occurs from May to June (ElSabh, 1979), so that the water column rapidly stratifies following a significant decrease in surface salinity and increase in temperature (from $2^{\circ} \mathrm{C}$ at the beginning of May to $8^{\circ} \mathrm{C}$ at the end of June). After the spring freshet, the water column remains stratified until the next winter. From May to November, density stratification shows important temporal variations at the sampling station (Fig. 3d). The more stratified periods coincide with the occurrence of surface waters of lower salinity $\left(\leqslant 27 \%\right.$ ) and higher temperature $\left(\geqslant 7^{\circ} \mathrm{C}\right)$, while less stratified periods are characterized by surface waters of higher salinity $(\geqslant 29 \%$ ) and lower temperature $\left(\leqslant 5^{\circ} \mathrm{C}\right)$. There is a significant relation between the advection of lower salinity waters and the occurrence of spring tides (Kendall's rank-order correlation coefficient between surface salinity and tidal amplitude $\tau=-0.201 ; 0.05 \geqslant P \geqslant 0.01)$. Turbidity is always high at the sampling station, the depth of $1 \%$ incident light penetration always being between 5 and $10 \mathrm{~m}$ (Fig. 3d).
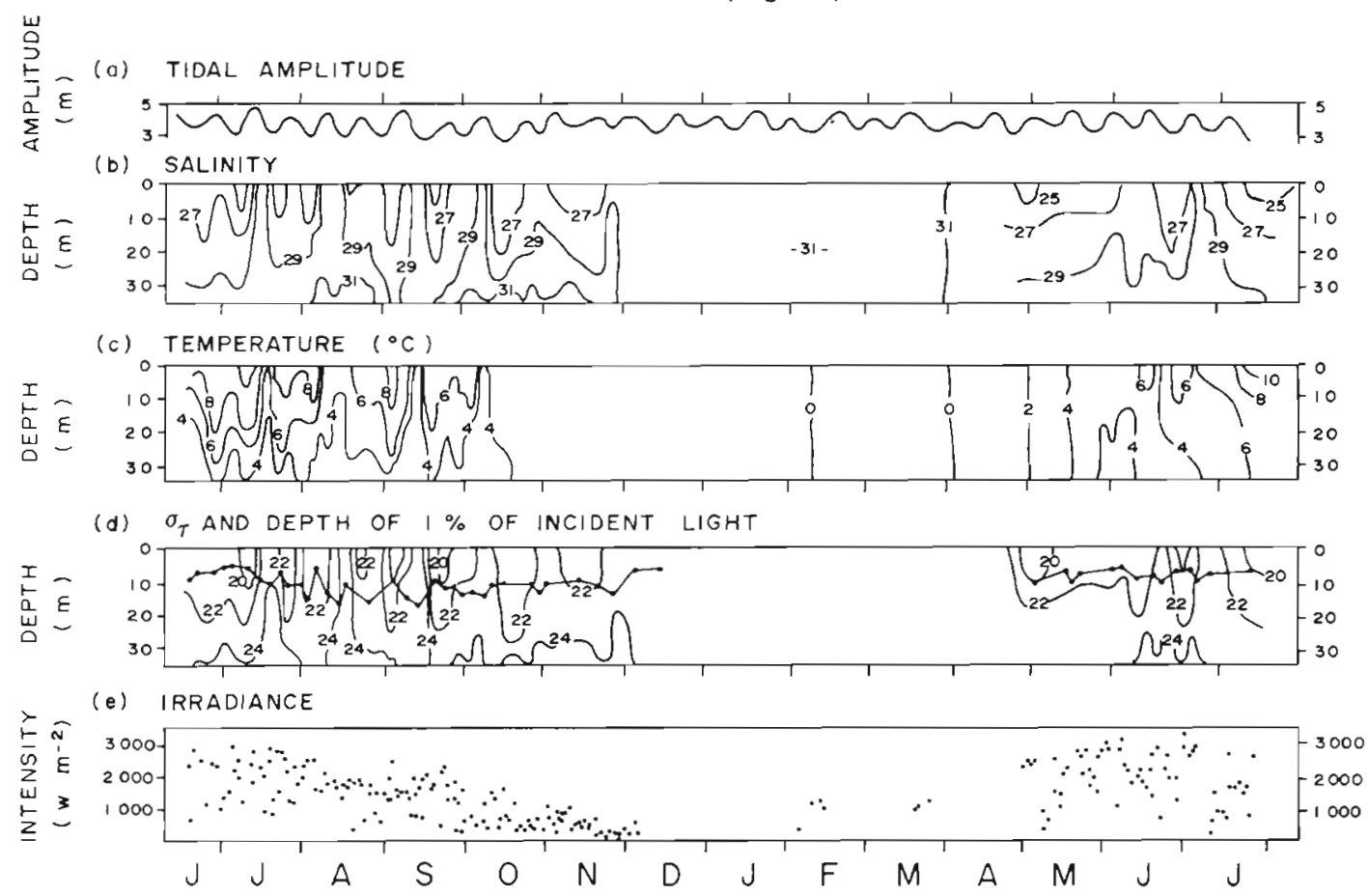

1979

1980

Fig. 3. Temporal variations of (a) tidal amplitude, (b) salinity, (c) temperature, (d) $\sigma_{u}$ (e) irradiance. The depth of $1 \%$ of incident light $(-)$ representing the lower limit of the photic zone is shown in $(d)$, superimposed on $\sigma_{t}$ isopleths 


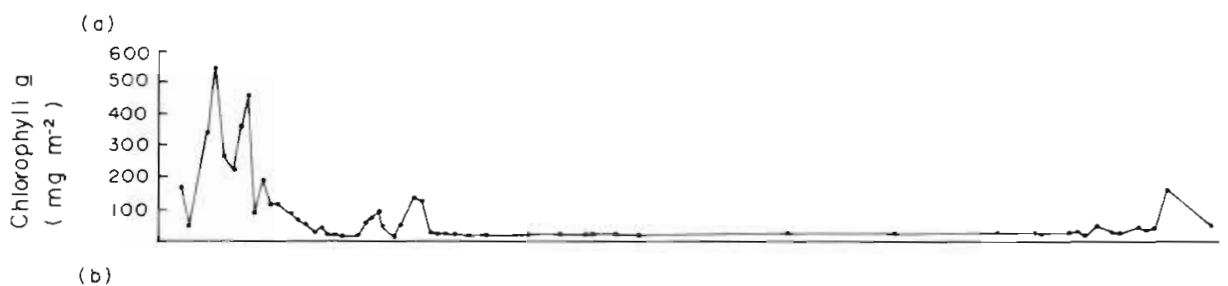

(b)

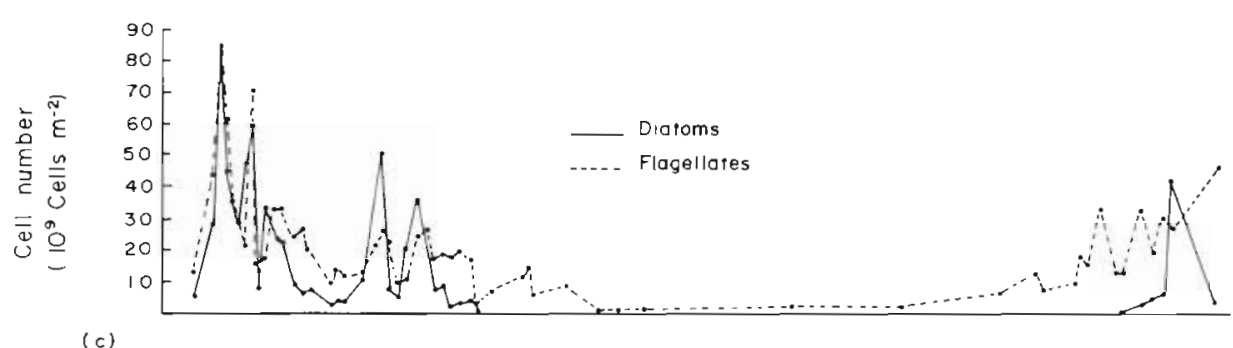

(c)
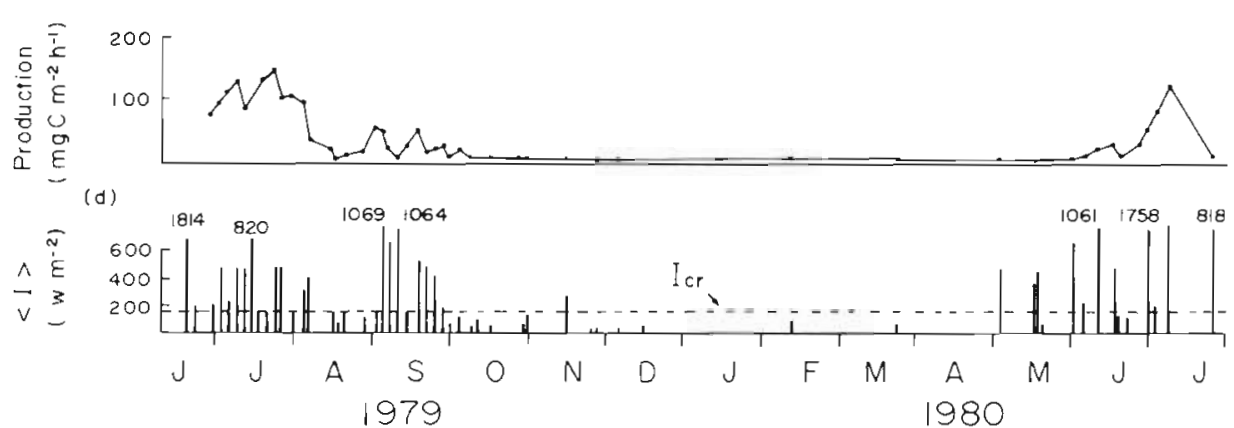

Fig. 4. Temporal variations of (a) chlorophyll concentration and (b) phytoplankton cell numbers integrated over the whole water column, (c) primary production integrated over the photic layer, (d) mean light intensity (Riley 1957, 1967) in the mixed layer. Dotted line: critical light intensity (see text) as defined by Riley (1957)

\section{Annual production cycle and phytoplankton succession}

Chlorophyll concentrations (Fig. 4a) and phytoplankton cell numbers (Fig. 4b), integrated over the whole water column, are low during winter (Oct to May) and high during summer (Jun to Sep). Maximum bloom values are observed in July, followed by a drastic decrease in August and production (Fig. 4c) closely follows that of chlorophyll and cell numbers. Because no other data base has been collected with the same frequency before, it is difficult to compare our data with those of other years. However, it seems that a seasonal variation cycle, characterized by a larger summer bloom and secondary blooms in the fall, is a regular variation pattern in the Estuary (Bugden et al., 1982)

Unlike diatoms, naked flagellates are present all year-round in the water column (Fig. 5). Lower numbers are observed during the winter period and peak values are reached in July $\left(83 \times 10^{9}\right.$ cells $\left.\mathrm{m}^{-2}\right)$ and September $\left(26 \times 10^{9}\right.$ cells $\left.\mathrm{m}^{-2}\right)$. Diatoms are observed in the water column only during summer, from mid-

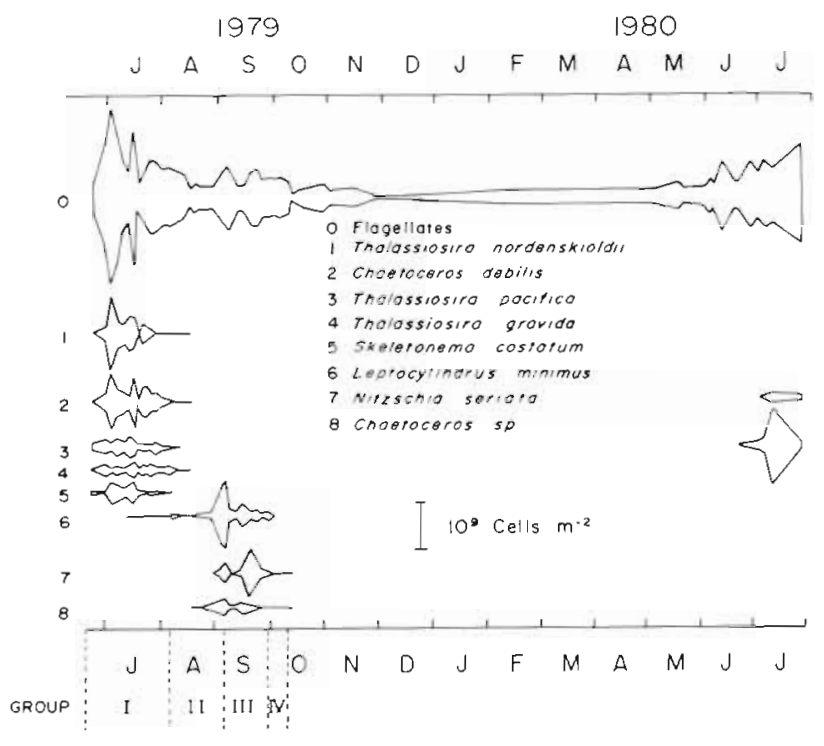

Fig. 5. Temporal variations of the number of flagellates and diatoms (accounting for more than $80 \%$ of the total number of diatoms) integrated over the whole water column. Boundaries of the different groups (see text and Fig. 6) are indicated at the bottom of the graph (vertical dotted lines) 


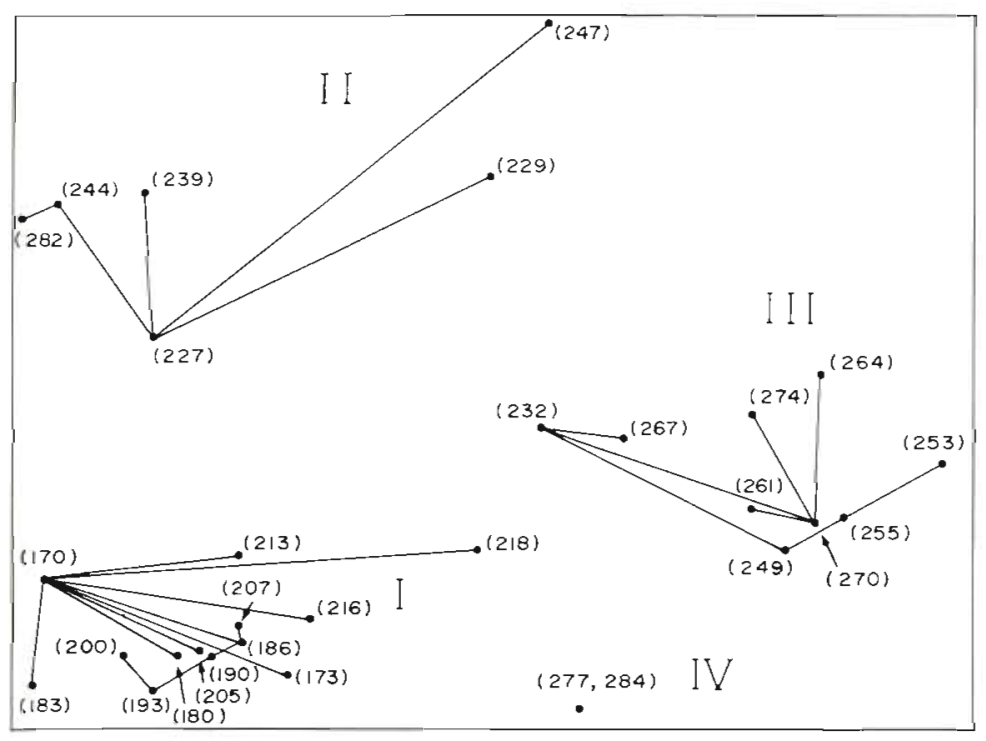

$A \times I S \quad I$
Fig. 6. Single linkage clustering of samples (solid lines: distance between samples $\mathrm{D}<0.6$ ), collected at the depth of $60 \%$ incident light between 19 June and 11 October 1979, represented in the reduced space of the first 2 scaling axes. The 4 resulting groups are numbered I to IV. Numbers in parentheses: Julian days
June or the beginning of July until the end of September. The community structure is dominated by different diatom species at different times in summer. Species responsible for the July bloom are Thalassiosira nordenskioldii and Chaetoceros debilis in 1979, and $T$. pacifica and $C$. debilis in 1980 . These species are gradually replaced in August by Leptocyclindrus minimus, Nitzschia seriata and Chaetoceros sp. which cause the September bloom.

For more objectivity, the succession of diatoms was defined statistically by grouping the samples according to their species composition. The numerical analysis was conducted on samples collected at the depth of $60 \%$ penetration of surface incident light (this depth is always in the mixed layer), between 19 June and 11 October 1979. Flagellates were excluded from this analysis since they were not identified to the species level. Besides, the simultaneous increases of flagellates with those of the diatoms, independent of the diatoms species present, suggest that these two taxonomic groups do not interfere with each other. The numerical analysis was carried out in 3 steps as described in details by Legendre and Legendre (1983). To summarize (1) the distance of Bray and Curtis (D) was first calculated between every pair of samples, then (2) single linkage clustering and (3) nonmetric multidimensional scaling were computed from the distance matrix (1). As a result, the position of every sample can be located with respect to the others (according to their species composition) in the reduced space of the multidimensional scaling. Fig. 6 shows the clustering (lines joining the samples) as projected on the first two axes of the multidimensional scaling (position of the samples relative to the first two axes). This figure clearly shows 4 distinct clusters corresponding to the following periods: Group I, from 19 June to 6 August; Group II, from 15 August to 4 September; Group III, from 6 September to 1 October; and Group IV, from 1 to 10 October. In taxonomic terms, these periods correspond to communities dominated by Thalassiosira nordenskioldii, $T$. pacifica, $T$. gravida, Chaetoceros debilis and Skeletonema costatum (Group I), Leptocylindrus minimus (Group II), Nitzschia seriata (Group III), and by much lower numbers of Nitzschia seriata and Chaetoceros sp. (Group IV) in October (Fig. 5).

To determine the influence of the environmental factors on the observed succession of phytoplankton species, a discriminant analysis using the physical factors listed in Table 1 was carried out on the 4 groups of Fig. 6. Nutrients were excluded from this analysis because they were always abundant at the sampling station (Fig. 2). This analysis indicates that significant between-groups heterogeneity can be found along two main axes $(P \leqslant 0.01$ for Axis 1 and $0.01 \leqslant P \leqslant 0.05$ for Axis 2 , according to the Wilks' $\lambda$ test). These first 2

Table 1. Relative contribution of physical variables to the first 2 discriminant axes. Lower boundary of mixed layer is defined by depth, where $\Delta \sigma_{\mathrm{t}} \geqslant 0.2$ unit $^{-1}$

\begin{tabular}{|lrr|}
\hline \multicolumn{1}{|c}{ Variables } & $\begin{array}{c}\text { Axis I } \\
68 \%\end{array}$ & \multicolumn{1}{c|}{$\begin{array}{c}\text { Axis II } \\
24 \%\end{array}$} \\
\hline Surface temperature & 1.366 & -0.460 \\
Surface salinity & $\mathbf{1 . 4 7 7}$ & 1.133 \\
Turbidity (Secchi) & -0.425 & -0.311 \\
Stratification $\left(\Delta \sigma_{\mathrm{t}}, 0-10 \mathrm{~m}\right)$ & -0.490 & -0.407 \\
Stratification $\left(\Delta \sigma_{\mathrm{t}}, 0-35 \mathrm{~m}\right)$ & 0.455 & 0.925 \\
Depth of the mixed layer & 0.409 & 0.182 \\
Irradiance (average over 3 d) & -0.136 & -0.703 \\
& & \\
\hline
\end{tabular}


classification functions explain $92 \%$ of the variance between-groups (Table 1) and result in the proper a posteriori classification of $83 \%$ of the samples. Spatial positions of these groups and their centroid by reference to the first two discriminant axes are shown in Fig. 7. Groups I, II and III are mainly discriminated along the first axis for which surface salinity and temperature are diagnostic. Group IV is discriminated along the second axis, which responds to the three variable surface salinity, density stratification and irradiance.

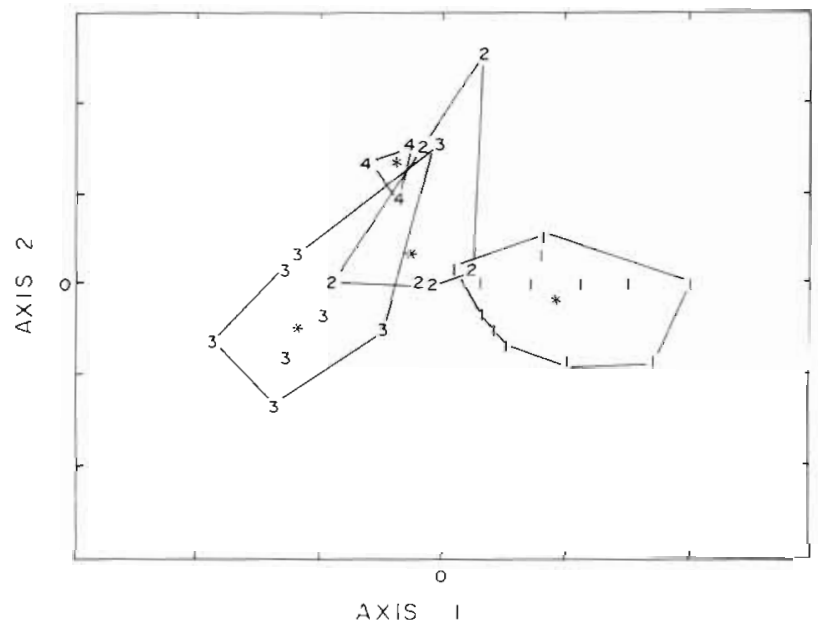

Fig. 7. Position of the 4 sample groups (Fig. 6) and of their centroids(") with respect to the first 2 discriminant axes

\section{DISCUSSION}

\section{Influence of density stratification and light intensity}

Following the concept of the 'critical depth' (Riley 1942; Sverdrup, 1953), many studies carried out in coastal environments have demonstrated the existence of a close relation between the occurrence of diatom blooms and the establishment of density stratification in the water column (Sinclair, 1978; Perry et al., 1983). Although it is recognized that stratification can reduce the loss, through sedimentation processes (Walsby and Reynolds, 1980), of phytoplankton cells from the photic zone, it is clear that the most important factor is light availability, since density stratification determines the mean light characteristics to which phytoplankton cells are subjected in the mixed layer (Riley, 1957, 1967; Barlow, 1958; Gieskes and Kraay, 1975; Hitchcock and Smayda, 1977). To evaluate the importance of the light regime for diatom numbers at our sampling station, the mean light intensity in the mixed layer, $\langle\mathbb{l}\rangle$, was estimated using the following equation (Riley, 1957, 1967):

$$
<\mathrm{I}>=\frac{\mathrm{I}_{0}\left(1-\mathrm{e}^{-\mathrm{kz}}\right)}{\mathrm{kz}}
$$

where $\mathrm{I}_{0}\left(\mathrm{~W} \mathrm{~m}^{-2}\right)=$ mean daily solar radiation; $\mathrm{k}=$ coefficient of extinction $(\mathrm{k}=1.44$ /Secchi depth; Holmes, 1970); $z=$ depth of mixed layer determined in this study by the depth where $\Delta \sigma_{\mathrm{t}}$ is $>0.2$ unit $^{-1}$ (Fournier et al., 1979). Assuming an extinction coefficient of $0.0138 \mathrm{~m}^{-1}$ for $1 \mathrm{mg}$ chlorophyll (Lorenzen, 1972), the relative importance of the living phytoplankton on the coefficient of extinction $\mathrm{k}$ in the Estuary varied between $0.01 \%$ in February and $48 \%$ during the major peak of biomass in July. Seasonal variations of $\langle I\rangle$ calculated for each sampling day, using the data of Table 2, are presented in Fig. 4d. Also shown in this figure is the level of the critical light intensity $I_{\mathrm{cr}}$ which has been set empirically at $193 \mathrm{~W} \mathrm{~m}^{-2}$ (Riley, 1957). $\mathrm{I}_{\mathrm{cr}}$ represents the theoretical light level under which phytoplankton growth is light limited in the mixed layer. It is evident from Fig. 3 and Table 2 that long-term seasonal variations of solar radiation and short-term variations of density stratification (depth of the mixed layer) result in large fluctuations of the mean light level in the mixed layer. During fall and winter, $\langle\mathrm{I}\rangle$ in the mixed layer has values generally lower than $\mathrm{I}_{c r}$ (Fig. $4 \mathrm{~d}$ ), resulting from a combination of low solar radiation and a deep mixed layer, so that diatoms are virtually absent from the water column. Due to higher freshwater runoff and solar heating of surface waters, a shallower mixed layer is generally observed during spring and summer, where $<$ I $>$ generally becomes $>\mathrm{I}_{\mathrm{cr}}$ and large numbers of diatoms are observed (except for May and June for reasons discussed below). At times, drastic decreases in diatoms numbers are however observed when $\langle I\rangle$ becomes $<\mathrm{I}_{\mathrm{Cr}}$, such as during August when tidal mixing includes the whole water column. These results therefore indicate that the presence or absence of diatoms and their relative numbers at the sampling station is mainly determined by the mean light level in the mixed layer, which is itself controlled by the superposition of short-term and long-term stratification cycles on the annual cycle of solar radiation.

Unlike diatoms, flagellates are present even in the fall and winter, when very low values of $\langle\mathrm{I}\rangle$ are observed in the mixed layer. This is consistent with the fact that flagellates are capable of maintaining themselves in the photic zone even in well mixed conditions (Watanabe, 1978; Malone and Chervin, 1979) and/or that they have a lower compensation irradiance (Takahashi et al., 1978). However, one should be careful here not to interpret this result as meaning complete independence of flagellates from stratification conditions, since it is evident from our data that flagellate abundance is related, during the spring and summer periods, to stratification conditions controlling the mean light and temperature (Fig. 4b, d).

In Long Island Sound, Bowman et al. (1981) have 
Table 2. Mean light intensity $\left(\mathrm{I}_{0}\right)$, depth of mixed layer $(\mathrm{z})$ and coefficient of extinction $(\mathrm{k})$ at sampling station, between 19 Jun 1979 and 25 Jul 1980

\begin{tabular}{|c|c|c|c|c|c|c|c|}
\hline $\begin{array}{l}\text { Sampling } \\
\text { dates }\end{array}$ & $\begin{array}{c}\mathrm{I}_{0}^{-} \\
\left(\mathrm{w}^{-2} \mathrm{~m}^{-2}\right)\end{array}$ & $\begin{array}{c}z \\
(m)\end{array}$ & $\begin{array}{c}k \\
\left(m^{-1}\right)\end{array}$ & $\begin{array}{l}\text { Sampling } \\
\text { dates }\end{array}$ & $\begin{array}{c}\mathrm{I}_{0} \\
\left(w^{-2} \mathrm{~m}^{-2}\right)\end{array}$ & $\begin{array}{c}z \\
(\mathrm{~m})\end{array}$ & $\underset{\left(m^{-1}\right)}{k}$ \\
\hline 19 Jun (1979) & 2968 & 3 & .360 & 1 Oct & 928 & 35 & .288 \\
\hline 22 Jun & 2968 & 35 & .379 & $4 \mathrm{Oct}$ & 614 & 16 & .320 \\
\hline $29 \mathrm{Jun}$ & 1996 & 22 & .436 & 9 Oct & 701 & 35 & .411 \\
\hline 2. Jul & 1822 & 7 & .480 & $11 \mathrm{Oct}$ & 1353 & 35 & .320 \\
\hline $5 \mathrm{Jul}$ & 1900 & 17 & .411 & $16 \mathrm{Oct}$ & 952 & 26 & .366 \\
\hline $9 \mathrm{Jul}$ & 1953 & 6 & .533 & $28 \mathrm{Oct}$ & 478 & 25 & .320 \\
\hline 12 Jul & 1784 & 7 & .480 & $30 \mathrm{Oct}$ & 701 & 25 & .288 \\
\hline $15 \mathrm{Jul}$ & 1932 & 5 & .411 & 1 Nov & 1093 & 25 & .306 \\
\hline $17 \mathrm{Jul}$ & 1930 & 35 & .288 & 14 Nov & 464 & 3 & .480 \\
\hline $19 \mathrm{Jul}$ & 1764 & 35 & .288 & 23 Nov & 135 & 10 & .411 \\
\hline $24 \mathrm{Ju}]$ & 2277 & 12 & .379 & 26 Nov & 338 & 25 & .366 \\
\hline $26 \mathrm{Jul}$ & 2412 & 12 & .360 & $5 \mathrm{Dec}$ & 280 & 20 & .620 \\
\hline 1 Aug & 1697 & 35 & .288 & 10 Febr (1980) & 1165 & 35 & .366 \\
\hline 4 Aug & 1982 & 15 & .360 & $23 \mathrm{Mar}$ & 1170 & 35 & .366 \\
\hline 6 Aug & 2127 & 13 & .360 & 2 May & 2156 & 6 & .720 \\
\hline 15 Aug & 1552 & 35 & .288 & 16 May & 1508 & 5 & .720 \\
\hline 17 Aug & 1010 & 35 & .288 & 17 May & 1741 & 5 & .720 \\
\hline 20 Aug & 1020 & 35 & .288 & 19 May & 2993 & 35 & .720 \\
\hline 27 Aug & 1300 & 35 & .288 & 1 Jun & 1996 & 5 & .576 \\
\hline 1 Sept & 1440 & 27 & .288 & 5 Jun & 1112 & 1 & .411 \\
\hline 4 Sept & 1837 & 4 & .300 & 10 Jun & 1788 & 2 & .576 \\
\hline 6 Sept & 1890 & 8 & .320 & 17 Jun & 1697 & 6 & .576 \\
\hline 10 Sept & 1440 & 2 & .320 & 19 Jun & 2050 & 35 & .411 \\
\hline 13 Sept & 1377 & 35 & .240 & 27 Jun & 1731 & 24 & .576 \\
\hline 18 Sept & 1788 & 8 & .366 & 30 Jun & 2746 & 3 & .411 \\
\hline 21 Sept & 1721 & 8 & .411 & $3 \mathrm{Jul}$ & 2577 & 35 & .320 \\
\hline 24 Sept & 1585 & 11 & .320 & $8 \mathrm{Jul}$ & 2417 & 3 & .366 \\
\hline 27 Sept & 1402 & 25 & .280 & $25 \mathrm{Jul}$ & 1348 & 3 & .366 \\
\hline
\end{tabular}

observed an increase of diatom numbers in a well mixed littoral region, while flagellates were dominating the community in the stratified waters offshore. We believe this apparent contradiction with our results is based on a different definition of stratification by these authors. In the St. Lawrence Estuary, we observed frequent differences of $o_{t} \geqslant 4.5$ over the first $35 \mathrm{~m}$. These density differences are at least 10 times larger than those observed by Bowman et al. (1981: Fig. 6c) in the offshore region of Long Island Sound $\left(\Delta \sigma_{t} 0-45 \mathrm{~m}\right.$ $\sim 0.5$ ). Therefore, a different way to interpret their data would be to consider that, in the deeper offshore region, the very weak density stratification cannot maintain diatoms in the photic zone, while flagellates can actively maintain themselves in this layer. Following this new interpretation, the presence of diatoms in the well mixed littoral zone can be explained by the shallower water depth, which sets the maximum depth of the mixed layer. Therefore, the loss of diatoms by sedimentation in the littoral zone is probably very limited and resuspension by vertical mixing keeps them in adequate light conditions. These 2 sets of apparently contradictory results emphasize the need for standard definitions of the indices (stability, stratification, mixing, etc.) that are used to characterize the vertical structure of a water column.

In the St. Lawrence Estuary, the phytoplankton bloom is late (end of Jun to beginning of Jul) compared to the Gulf of St. Lawrence where the phytoplankton bloom occurs in April-May (Steven, 1974; Sevigny et al., 1979). Sinclair (1978) suggested that this delay can be attributed to the higher turbidity of the estuarine surface waters in the spring, which would limit phytoplankton growth. However, high values of $\langle\mathrm{l}\rangle$ observed in May and June (Fig. 4d) indicate that light is not limiting in the mixed layer at this time of the year and, consequently, that turbidity cannot be responsible for the late spring bloom. Other workers have attributed the reduced phytoplankton biomass observed in the spring in some estuaries to the high freshwater runoff, which would prevent the accumulation of cells in the mixed layer (Malone, 1977b; Côté and Lacroix, 1979; Sinclair et al., 1981). Our data show a progressive increase in flagellates in May and June (Fig. 4), with a parallel increase in the specific growth rate (values of $\mathrm{P} / \mathrm{B}$ not given here). These results indicate 
that the low phytoplankton biomass in the spring reflects more the structure of the community, which is dominated by flagellates with low chlorophyll content at this time of the year, than the absence of phytoplankton growth. Flagellates are always present in the water column (Fig. 4 and 5) and are also very abundant in waters of continental origin (Wangersky, 1977; Malone and Chervin, 1979; Bowman et al., 1981). On the contrary, diatoms are usually absent from the water column in the winter period and their growth is dependent upon resuspension in the photic zone of resting spores that have sedimented in the fall (Durbin, 1978) and/or of advection of cells from an upstream region, and/or from the upstream transportation by deep currents of cells produced downstream (Margalef, 1958; Winter et al., 1975; Malone, 1977a; Roman and Tenore, 1978; Malone and Chervin, 1979). Therefore, it can be suggested that the decrease in eddy exchange between the surface and deeper layer in spring due to the increasing freshwater runoff discharge (Bugden, 1981) prevents the seeding of the photic layer by diatom cells.

\section{Influence of temperature and salinity}

Short-term variations of density stratification during the summer are apparent in Fig. 3d. These short-term variations are linked to the displacement of a frontal structure established between the well mixed upstream and the well stratified downstream waters in the St. Lawrence Estuary (Gagnon and El-Sabh, 1980). Our data therefore reflect the fortnightly tidal advection $\left(\mathrm{M}_{\mathrm{f}}\right)$ of this frontal system with respect to the location of our sampling station. Other authors have observed important variation in phytoplankton biomass associated with the presence of frontal structures in estuaries (Sinclair et al., 1981) and on the continental shelf (Pingree et al., 1978; Fournier et al., 1979; Iverson et al., 1979). Whether the biomass variations in those frontal structures are controlled by stratification, temperature or the mean light regime is difficult to establish since these factors are interrelated (Table 3). However, the partial correlation analyses of Table 4 strongly suggest that temperature has the most influence on both diatom and flagellate abundance during the summer period in the Estuary. This result is not surprising since the effect of temperature on phytoplankton growth $(\mathrm{P} / \mathrm{B})$ has been well demonstrated (Eppley, 1972; Harrison and Platt, 1980). Moreover, in the case of the flagellates, a significant year-round relation has been observed between their abundance and temperature (Fig. 8), which confirms the results obtained in other coastal and estuarine environments (Briant, 1975; Durbin et al., 1975; Holligan and Har-
Table 3. Pearson's coefficient of linear correlation between biological (log-transformed) and physical variables (19 Jun to 1 Oct)

\begin{tabular}{|c|c|c|c|c|}
\hline & Diatoms & $\begin{array}{c}\text { Flagel- } \\
\text { lates }\end{array}$ & $\begin{array}{c}\text { Strati- } \\
\text { fication }\end{array}$ & $\langle\mathrm{I}\rangle^{2}$ \\
\hline Flagellates & \multicolumn{4}{|l|}{$0.77^{\cdots}$} \\
\hline Stratification ${ }^{1}$ & $0,41^{\circ}$ & \multicolumn{3}{|l|}{$0.49^{\cdots}$} \\
\hline$\langle\mathrm{I}\rangle^{2}$ & $0.37^{\circ}$ & $0.36^{\circ}$ & \multicolumn{2}{|l|}{0.21} \\
\hline Temperature $^{3}$ & $0.58^{\cdots}$ & $0.62 \cdots$ & $0.80^{\cdots}$ & \multirow[t]{2}{*}{0.28} \\
\hline \multicolumn{4}{|c|}{$\begin{array}{l}\cdot 0.01 \leqslant p \leqslant 0.05 \\
\because p \leqslant 0.01\end{array}$} & \\
\hline \multicolumn{5}{|c|}{$\begin{array}{l}1 \text { Difference in } \sigma_{t} \text { unit over the water column }(35 \mathrm{~m}) \\
2 \text { Mean light intensity in the mixed layer (see text) } \\
{ }_{3} \text { Surface temperature }\end{array}$} \\
\hline
\end{tabular}

Table 4. Partial Pearson's coefficient of linear correlation between diatoms and flagellates numbers (log-transformed) respectively and various physical factors (19 Jun to 1 Oct 1979)

\begin{tabular}{|c|c|c|c|c|}
\hline $\begin{array}{l}\text { Dependant } \\
\text { variable }\end{array}$ & $\begin{array}{l}\text { Independant } \\
\text { variable }\end{array}$ & $\begin{array}{l}\text { Controlled } \\
\text { variables } \\
\text { (simul- } \\
\text { taneously) }\end{array}$ & $\mathbf{r}$ & $\begin{array}{l}\text { Signi- } \\
\text { ficance }\end{array}$ \\
\hline \multirow[t]{3}{*}{ Diatoms } & Temperature ${ }^{1}$ & $\begin{array}{c}\qquad \mathrm{I}> \\
\text { Stratification }\end{array}$ & 0.43 & 0.012 \\
\hline & $<\mathrm{I}\rangle^{2}$ & $\begin{array}{l}\text { Temperature } \\
\text { stratification }\end{array}$ & 0.27 & 0.086 \\
\hline & Stratification ${ }^{3}$ & $\begin{array}{c}\text { Temperature } \\
<\mathrm{I}>\end{array}$ & -0.12 & 0.280 \\
\hline \multirow[t]{3}{*}{ Flagellates } & Temperature ${ }^{1}$ & $\begin{array}{c}<\mathrm{I}> \\
\text { Stratification }\end{array}$ & 0.40 & 0.019 \\
\hline & $<\mathrm{I}\rangle^{2}$ & $\begin{array}{l}\text { Temperature } \\
\text { stratification }\end{array}$ & 0.24 & 0.112 \\
\hline & Stratification $^{3}$ & $\begin{array}{l}\text { Temperature } \\
<\mathrm{I}>\end{array}$ & -0.01 & 0.484 \\
\hline \multicolumn{5}{|c|}{$\begin{array}{l}1 \text { Surface temperature } \\
2 \text { Mean light intensity in mixed layer (see text) } \\
{ }^{3} \text { Difference in } \sigma_{t} \text { unit over water column }(35 \mathrm{~m} \text { ) }\end{array}$} \\
\hline
\end{tabular}

bour, 1977; Malone, 1977b; Malone and Chervin, 1979; Walting et al., 1979; Malone and Neale, 1981). Such a relation has not been observed for the diatoms, because their presence or absence in the water column is rather related to the annual variations of the mean light intensity $(<I>)$ in the mixed layer (which depends on both solar irradiance and vertical stratification).

In the St. Lawrence Estuary, diatoms show a well defined succession of species during the summer (Fig. 5 and 6). A discriminant analysis has indicated that the succession from Group I to Group III is mainly related to low frequency variations of surface temperature and salinity (Table 1). However, mean differences 


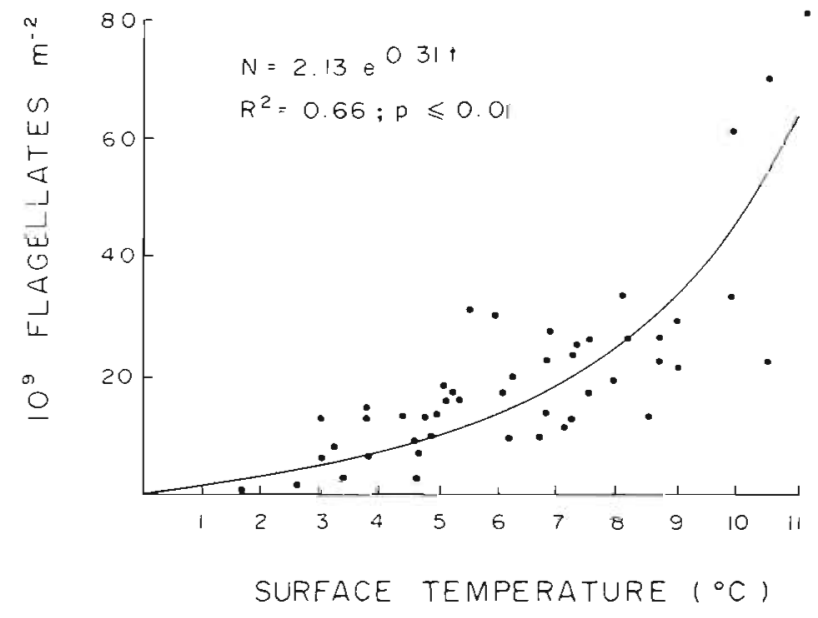

Fig. 8. Relation between flagellate numbers and surface temperature

in temperature and salinity from one group of the succession to the other are relatively small (Table 5), compared to the wide range of salinities and temperatures over which those diatom species can grow (Braarud, 1962; Smayda, 1973; Durbin, 1974; Bonin et al., 1981). With respect to this problem, Malone and Neale (1981) have suggested that, in estuaries with intense vertical mixing and high rates of sedimentation (high numbers of diatoms are often observed under the mixed layer in the St. Lawrence Estuary), optimal conditions are required for diatom growth. For example, Thalassiosira nordenskioldii shows maximum growth rates at $10^{\circ} \mathrm{C}$ (Braarud, 1962; Durbin, 1974 ) and a high rate of resting spore formation (68 to $96 \%$ ) at temperatures between 0 and $5^{\circ} \mathrm{C}$ (Durbin, 1978). In the Estuary, maximum numbers of $T$. nordenskioldii are observed in July when surface temperature is around $10^{\circ} \mathrm{C}$ (Fig. $3 \mathrm{C}$ ) and a rapid decrease in numbers occurs in August when the surface temperature goes below $5{ }^{\circ} \mathrm{C}$. Other diatom species such as Leptocylindrus minimus and Nitzschia seriata become dominant under these temperature conditions. These results therefore suggest that the long-term tempera-

Table 5. Mean temperature, salinity, stratification $\left(\Delta \sigma_{1}\right.$ between 0 and $35 \mathrm{~m}$ ) and irradiance, for period of time corresponding to each diatom group (see text and Fig. 5 and 6)

\begin{tabular}{|lcccc|}
\hline Group & $\begin{array}{c}\text { Tempera- } \\
\text { ture } \\
\left({ }^{\circ} \mathrm{C}\right)\end{array}$ & Salinity & $\begin{array}{c}\text { Strati- } \\
\text { fication } \\
\left(\Delta \sigma_{\nu}\right)\end{array}$ & $\begin{array}{c}\text { Irradiance } \\
\left(\mathrm{w} \mathrm{m}^{-2}\right)\end{array}$ \\
\hline I & 8.7 & 26.84 & 3.58 & 19,779 \\
II & 6.8 & 28.22 & 2.15 & 14,007 \\
III & 6.4 & 26.94 & 2.58 & 15,181 \\
IV & 5.0 & 28.56 & 1.80 & 7,016 \\
\hline
\end{tabular}

ture variations have an important effect on the control of diatom succession.

Unlike Groups I to III, Group IV is associated with the second discriminant axis (Fig. 7) for which surface salinity, density stratification and irradiance are identified as controlling factors (Table 1). Mean light intensity $\langle\mathrm{I}\rangle$ is then lower than $\mathrm{I}_{\mathrm{Cr}}$ (Fig. $4 \mathrm{~d}$ ), which is an indication that decreasing light intensity in the mixed layer rather than temperature explains the progressive disappearance of diatoms at the beginning of October.

Salinity was also identified as a significant controlling factor for both discriminant axes, but it is unlikely that the small differences observed in mean salinity (Table 5) could explain the differential growth of such euryhaline diatom species as those observed in this study. The significant linear correlation between temperature and salinity ( $\mathrm{r}=-0.66 ; \mathrm{p} \leqslant 0.01$ ), and temperature and stratification (Table 3) probably explains this results.

\section{Hierarchical control of succession by physical factors}

In the oceanic environment, nutrients are abundant in the water column following winter mixing so that, when $\langle\mathrm{I}\rangle$ becomes $\geqslant \mathrm{I}_{\mathrm{cr}}$ in the mixed layer, a bloom of phytoplankton rapidly takes place (Gieskes and Kraay, 1975). The blooming species are mainly small diatoms with high growth rates that are characteristic of the Stage I of succession as defined by Margalef (1958). This phytoplankton bloom causes a rapid decrease in nutrient concentrations, so that high growth rates can no longer be sustained. Thus phytoplankton cells with lower and lower growth rates (Stages II and III: Margalef, 1958) are gradually favoured, replacing the faster growing species. These low growing species dominate the community structure for as long as the low nutrient conditions hold. Mixing caused by meteorological events may occasionally set back succession by favoring faster growing species (Margalef, 1962). The fall overturn of the water column may also favour faster growing species for some time (the fall bloom) before the mean light intensity in the mixed layer becomes again limiting $\left(<\mathrm{I}><\mathrm{I}_{\mathrm{cr}}\right.$ ) (Holligan and Harbour, 1977). In estuarine environments, such as the St. Lawrence Estuary, the high frequency of destabilization maintains nutrients almost continuously above limiting concentration in the mixed layer, although a seasonal pattern of utilization is observed (Fig. 2). Therefore, the basic growth conditions are continuously favouring higher growth rate taxa $(1$ to 2 divisions $\mathrm{d}^{-1}$ in natural conditions), such as the small diatoms and naked flagellates encountered in our study. These diatom species are characteristic of an early stage of succession (Stage I). 
While the basic growth rate characteristics are set by the frequency of destabilization of the water column, other factors such as the mean light intensity in the mixed layer (combined effect of solar radiation and density stratification) and temperature continue to vary on a seasonal cycle, gradually changing the conditions for optimal metabolic activity of the cells in the mixed layer. As shown above, the mean light intensity in the mixed layer determines the time of appearance and disappearance of diatoms and also probably other nonmotile form in the water column. On the other hand, seasonal variations in temperature and possibly other environmental factors are responsible for the succession of diatom species observed during the growing season.

In the oceanic environment, succession thus appears to be mainly autogeneously (Smayda, 1980) controlled, since the range of growth rates or the type of cells selected is itself determined by the depletion of nutrient caused by phytoplankton growth. In a tidal estuary, the high frequency of destabilization usually maintains a continuously high level of nutrients, which limits the autogenous control of succession. In this case, phytoplankton succession is mostly allogenously controlled. These 2 cases represent opposite extremes in the range of possible succession types and many intermediary conditions can probably be found in nature. It is the duration of the periods of stability which will determine the degree of the autogenous control and consequently the complexity or the maturity reached by a phytoplankton community. Therefore, the same general factors govern the succession of phytoplankton in all marine environment, whether oceanic, shelf or estuarine.

From the above considerations, it follows that there

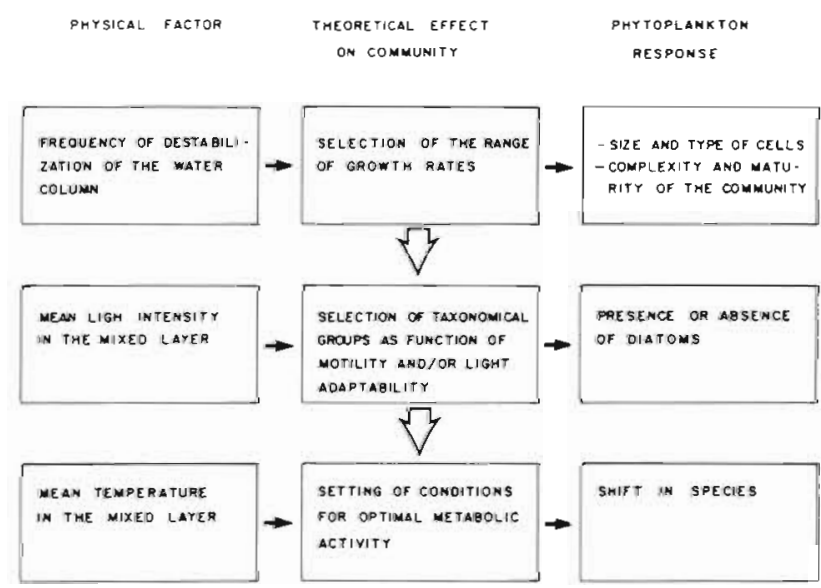

Fig. 9. Hierarchical control of phytoplankton succession by physical factors. Large arrows: direction of hierarchy; small arrows: theoretical effect of each factor on the community. Last column: observed phytoplankton response in natural conditions exists a hierarchy in the relative importance of the different physical factors as to phytoplankton succession. Fig. 9 schematically illustrates this concept. The most important factor is the frequency of destabilization of the water column which determines nutrient limitation in the mixed layer and consequently selects a range of growth rates. Then, the mean light intensity in the mixed layer, which is dependent upon solar radiation and density stratification cycles, determines the presence or absence of diatoms in the mixed layer $\left(<\mathrm{I}>\right.$ compared to $\mathrm{I}_{\mathrm{cr}}$ ). Finally, the temperature cycle sets the conditions for optimal metabolic activities, to which the phytoplankton community responds by a shift or a succession of species within the present range of possible growth rates. This hierarchical control of phytoplankton succession is consistent with the idea of Harris (1980) that high or low frequency perturbations of long duration in the physical environment ultimately lead to community changes or species succession. It also stresses the fundamental significance of the frequency of destabilization in the aquatic environment which determines not only the potential of phytoplankton production (Legendre, 1981) but also the type of phytoplankton succession.

Acknowledgements. We thank L. Therriault, L. Pelletier, J.-Y. Bellavance, J.-Y. Anctil and M. Boudreau for assistance in the field and the laboratory and L. Corriveau for drafting the figures. Dr. A. Cardinal (Dep. Biology, Univ. Laval) provided expertise with the taxonomic work. Discussion with T.J. Smayda have been most useful. This research was funded by the Champlain Center for Marine Sciences and Surveys Department of Fisheries and Oceans, and by GIROQ (Groupe interuniversitaire de recherche océanographiques du Québec) thanks to the Ministère de l'Education du Québec and to the Natural Sciences and Engineering Research Council of Canada. The first author (M. L.) was supported by a postgraduate scholarship from the Ministère de l'Education du Québec.

\section{LITERATURE CITED}

Barlow, J. P. (1958). Spring changes in phytoplankton abundance in a deep estuary, Hood Canal, Washington. J. mar. Res. 17: 53-67

Bonın, D. J., Maestrini, S. Y., Leftly, J. W. (1981). Some processes and physical factors that affect the ability of individual species of algae to compete for nutrient partition. In: Platt, T. (ed.) Physiological bases of phytoplankton ecology. Can. Bull. Fish. Aquat. Sci. 210: 292-309

Bowman, M. J., Esaias, W. E., Schnitzer, M. B. (1981). Tidal stirring and the distribution of phytoplankton in Long Island and Block Island Sound. J. mar Res. 39: 587-603

Braarud, T. (1962). Species distribution in marine phytoplankton. J. oceanogr. Soc. Japan. 20th Anniversary volume: $628-649$

Briant, F. J. P. (1975). Seasonal variations and associations of southern Californian nearshore phytoplankton. J. Ecol. 64 : $821-835$

Bugden, G. L. (1981). Salt and heat budgets for the Gulf of St. Lawrence. Can. J. Fish. aquat. Sci. 38: 1153-1167 
Bugden, G. L., Hargrave, B. T., Sinclair, M. M., Tang, C. L., Therriault, J. C., Yeats, P. A. (1982). Freshwater runoff effects in the marine environment: the Gulf of St. Lawrence example. Can. Tech. Rep. Fish. Aquat. Sci. 1078 $1-89$

Côté, R., Lacroix, G. (1979). Influences des débits élevés et variables d'eau douce sur le régime saisonnier de production primaire d'un fjord subarctique. Oceanologia Acta 2: 299-306

Durbin, E. G. (1974). Studies on the autecology of the marine diatom Thalassiosira nordenskioldii Cleve. 1. The influence of daylength, light intensity, and temperature on growth. J. Phycol. 10: 220-225

Durbin, E. G. (1978). Aspects of the biology of resting spores of Thalassiosira nordenskioldii and Detonula confervacea. Mar. Biol. 45: 31-37

Durbin, E. G., Krawiec, R. W., Smayda, T. J. (1975). Seasonal studies on the relative importance of different size fractions of phytoplankton in Narragansett Bay (USA). Mar. Biol. 32: 271-287

El-Sabh, M. I. (1979). The lower St. Lawrence Estuary as a physical oceanographic system. Naturaliste can. 106: 4473

Eppley, R. W. (1972). Temperature and phytoplankton growth in the sea. Fish. Bull. U. S. 70: 1063-1085

Fournier, R. O., Vandet, M., Wilson, J. S., Hargreaves, N. B. (1979). Influence of the shelf-break front off Nova Scotia on phytoplankton standing stock in winter. J. Fish. Res. Bd Can. 36: 1228-1237

Gagnon, M., El-Sabh, M. I. (1980). Effects de la marée interne et des oscillations de basse fréquence sur la circulation côtière dans l'estuaire du Saint-Laurent. Naturaliste can. 107: 159-174

Gieskes, W. W. C., Kraay, G. W. (1975). The phytoplankton spring bloom in Dutch coastal waters of the North Sea. Neth. J. Sea Res. 9: 166-196

Harris, G. P. (1980). Temporal and spatial scales in phytoplankton ecology. Mechanisms, methods, models, and management. Can. J. Fish. aquat. Sci. 37: 877-900

Harris, G. P., Piccinin, B. B. (1980). Physical variability and phytoplankton communities IV. Temporal changes in the phytoplankton community of a physically variable lake. Arch. Hydrobiol. 89: 447-473

Harrison, W. G., Platt, T. (1980). Variations in assimilation number of coastal marine phytoplankton: effects of environmental co-variates. J. Plankton Res. 2: 249-260

Hitchcock, G. L., Smayda, T. J. (1977). The importance of light in the initiation of the 1972-1973 winter-spring diatom bloom in Narragansett Bay. Limnol. Oceanogr. 22: $126-131$

Holligan, P. M., Harbour, D. S. (1977). The vertical distribution and succession of phytoplankton in the western English Channel in 1975 and 1976. J. mar. biol. Ass. U. K. 57: 1075-1093

Holmes, R. W. (1970). The Secchi disk in turbid coastal waters. Limnol. Oceanogr, 15: 688-694

Holm-Hansen, O., Lorenzen, C. J., Holmes, R. N., Strickland, J. S. (1965). Fluorometric determination of chlorophyll. J. Cons. int. Explor. Mer 30: 3-15

Hutchinson, G. E. (1967). A treatise on limnology, Vol. 2, Introduction to lake biology and the limnoplankton. Wiley, New York

Ignatiades, L. (1979). The influence of water stability on the vertical structure of a phytoplankton community. Mar. Biol. 52: 94-104

Iverson, R, L., Whitledge, T. E., Goering, J. J. (1979) Chlorophyll and nitrate fine structure in the southeastern
Bering Sea shelf break front. Nature, Lond. 281: 664-666 Legendre, L. (1981). Hydrodynamic control of marine phytoplankton production: the paradox of stability. In: Nihoul, J. C. J. (ed.) Ecohydrodynamics. Elsevier, Amsterdam, p. 191-207

Legendre, L., Legendre, P. (1983). Numerical ecology. Elsevier, Amsterdam

Lorenzen, C. J. (1972). Extinction of light in the ocean by phytoplankton. J. Cons. perm. int. Explor. Mer 34: 262-267

Lund, J. W. G., Kipling, C, Lecren, E. D. (1958). The inverted microscope method of estimating algal numbers and the statistical basis of estimations by counting. Hydrobiologia 11: $143-170$

Malone, T. C. (1977a). Environmental regulation of phytoplankton productivity in the lower Hudson Estuary Estuar. coast. mar. Sci. 5: 157-171

Malone, T. C. (1977b). Light-saturated photosynthesis by phytoplankton size fractions in the New York Bight, U. S. Mar. Biol. 42: 281-292

Malone, T. C., Chervin, M. B. (1979). The production and fate of phytoplankton size fractions in the plume of the Hudson River, New York Bight. Limnol. Oceanogr. 24: 683-696

Malone, T. C., Neale, P. J. (1981). Parameters of light-dependent photosynthesis for phytoplankton size fraction in temperate estuarine and coastal environments. Mar. Biol. 61: 289-297

Margalef, R. (1958). Temporal succession and spatial heterogeneity in phytoplankton. In: Buzzati-Traverso, A. A. (ed.) Perspective in marine biology. University of California Press, Berkeley and Los Angeles, p. 323-349

Margalef, R. (1962). Succession in marine populations. Adv. Front. Plant Sci. 2: 137-188

Margalef, R. (1963). On certain unifying principles in ecology Am. Nat. 97: 357-374

Margalef, R. (1967). Some concepts relative to the organization of plankton. Oceanogr. mar. Biol. A. Rev. 5: 257-289

Margalef, R. (1978). Life-forms of phytoplankton as survival alternatives in an unstable environment. Oceanologica Acta 1: 493-509

Margalef, R., Estrada, M., Blasco, D. (1979). Functional morphology of organisms involved in red tides, as adapted to decaying turbulence. In: Taylor, L., Seliger, H. H. (ed.) Toxic dinoflagellate blooms, Vol. I. Elsevier, North-Holland, p. 89-94

Martin, J. H. (1970). Phytoplankton-zooplankton relationship in Narragansett Bay. IV. The seasonal importance of grazing. Limnol. Oceanogr. 15: 413-418

Patten, B. C., Mulford, R. A., Warrinner, J. E. (1963). An annual phytoplankton cycle in the lower Chesapeake Bay. Chesapeake Sci. 4: 1-20

Регту, R. I., Dilke, B. R., Parson, T. R. (1983). Tidal mixing and summer plankton distribution in Hecate Strait, British Columbia. Can. J. Fish. aquat. Sci. 40: 871-887

Pingree, R. D., Holligan, P. M., Mardell, G. T. (1978). The effect of vertical stability on phytoplankton distributions in the summer on the northwest European shelf. Deep Sea Res. 25: 1011-1028

Riley, G. A. (1942). The relationship of vertical turbulence and spring diatom flowerings. $J$. mar. Res. S.: $67-87$

Riley, G. A. (1957). Phytoplankton of the north central Sargasso Sea. Limnol. Oceanogr. 2: 252-270

Riley, G. A. (1967). The plankton of estuaries. In: Lauff, G. (ed.) Estuaries. Am. Ass. Adv. Sci. Pub. 83, Washington, D. C., p. $316-326$

Roman, M. R., Tenore, K. R. (1978). Tidal resuspension in Buzzards Bay, Massachusetts. 1. Seasonal changes in the 
resuspension of organic carbon and chlorophyll a. Estuar. coast. mar. Sci. 6: $37-46$

Ryther, J. H., Sanders, J. G. (1980), Experimental evidence of zooplankton control of the species composition and size distribution of marine phytoplankton. Mar. Ecol. Prog. Ser. 3: 279-283

Sévigny, J.-M., Sinclair, M., El-Sabh, M., Poulet, S., Coote, A. (1979). Summer plankton distribution associated with the physical and nutrient properties of the northwestern Gulf of St. Lawrence. J. Fish. Res. Bd Can. 36: 187-203

Sinclair, M. (1978). Summer phytoplankton variability in the lower St. Lawrence Estuary. J. Fish. Res. Bd Can. 35: 1171-1185

Sinclair, M., Subba Rao, P. V., Couture, R. (1981). Phytoplankton temporal distribution in estuaries. Oceanologia Acta 4: $239-246$

Smayda, T. J. (1963). Succession of phytoplankton, and the ocean as an holocoenotic environment. In: Oppenheimer, C. H. (ed.) Symposium on marine microbiology. Thomas, Springfield, p. 260-274

Smayda, T. J. (1973). The growth of Skeletonema costatum during a winter-spring bloom in Narragansett Bay, R. I. Norw. J. Bot. 20: 219-247

Smayda, T. J. (1980). Phytoplankton species succession. In: Morris, I. (ed.) The physiological ecology of phytoplankton. University of California Press, Berkeley and Los Angeles, p. $493-570$

Steven, D. M. (1974). Primary and secondary production in the Gulf of St. Lawrence. McGill Univ. Mar. Sci. Cent. MS Rep. 26: 1-116
Strickland, J. S. H., Parsons, T. R. (1972). A practical handbook of seawater analysis. Bull. Fish. Res. Bd Can. 167: $1-310$

Sverdrup, H. V. (1953). On conditions for the vernal blooming of phytoplankton. J. Cons. perm. int. Explor. Mer 18: 287-295

Takahashi, M., Barwell-Clarke, J., Whítney, F., Koeller, P. (1978). Winter conditions of marine plankton populations in Saanich Inlet, B. C., Canada. I. Phytoplankton and its surrounding environment. J. exp. mar. Biol. Ecol. 31: 283-301

Walsby, A. E., Reynolds, C. S. (1980). Sinking and floating, In Morris, I. (ed.) The physiological ecology of phytoplankton. University of California Press, Berkeley and Los Angeles, p. 371-412

Walting, L., Bottom, D., Pembroke, A., Maurer, D. (1979) Seasonal variations in Delaware Bay phytoplankton community structure. Mar. Biol. 52: 207-215

Wangersky, P. J. (1977). The role of particulate matter in the productivity of surface waters. Helgoländer wiss. Meeresunters. 30: 546-564

Watanabe, L. (1978). Factors controlling the winter dominance of nanoflagellates in Saanich Inlet. M. Sc. thesis, University of British Columbia, Vancouver, B. C.

Winter, D. F., Banse, K., Anderson, G. C. (1975). The dynamics of phytoplankton blooms in Puget Sound, a Fjord in the northwestern United States. Mar. Biol. 29: 139-176

Yentsch, C. S., Menzel, D. W. (1963). A method for the determination of phytoplankton chlorophyll and phaeophytin by fluorescence. Deep Sea Res. 10: 221-231

This paper was submitted to the editor; it was accepted for printing on June 9, 1984 